\title{
DEVELOPMENT OF A METHOD TO EVALUATE THE EFFICIENCY OF NANOSCALE ZERO-VALENT IRON (NZVI) TO DEGRADE POLLUTANTS
}

\author{
G. A. FERRARI ${ }^{1}$, F. S. de O CRUZ ${ }^{1}$, G. A. PUIATTI ${ }^{1}$, L. D. de M. MORAES ${ }^{1}$, A. F de $\operatorname{OLIVEIRA}^{1}$ and \\ R. P. LOPES ${ }^{1}$
}

${ }^{1}$ Federal University of Viçosa, Chemical Department, Viçosa, Minas Gerais, Brazil, renataplmoreira@ gmail.com

\begin{tabular}{l} 
A R T I C L E I N F O \\
\hline Article history: \\
Received 2019-12-20 \\
Accepted 2019-06-28 \\
Available online 2019-06-30 \\
pa l a v ra s - ch a ve \\
Ferro de Valencia Zero; \\
Otimização; \\
Eficiência de remoção \\
Validação de método \\
ke y w o r $d s$ \\
Zero-valent iron, \\
Optimization, \\
Removal efficiency, \\
Method validation. \\
\end{tabular}

A B S T R A C T

Iron nanoparticles (nZVI) stand out in environmental remediation due to their high reactivity. However, they have low chemical stability when exposed to oxygen and water, reducing their effectiveness. The objective of this work was to develop and validate a method to evaluate the efficiency of nZVI from synthetic lots LO1 and L02, from the degradation of dyes, orange and methyl violet (MO and MV). The previous degradation tests provided the best results for $M O\left(\sim 100 \%\right.$ degradation, 12 min reaction, $0.5 \mathrm{~g} \mathrm{~L}^{-1}$ dose). The optimization using Factorial Planning obtained the optimal condition, $C_{M O}=5.98 \mathrm{~mol} \mathrm{~L}^{-1}$ and $D_{n \mathrm{ZVI}}=$ $0.56 \mathrm{~g} \mathrm{~L} \mathrm{~L}^{-1}$. The Boltzmann model fitted the results obtained $\left(R^{2}=0.993\right)$. Finally, $a$ mathematical relationship was obtained that provided equivalent doses of LO1 and LO2 in relation to the Standard. The applied mathematical adjustments presented $R^{2}>0.99$ and errors $<4 \%$.

\section{R E S U M O}

As nanopartículas de ferro (nZVI) destacam-se na remediação ambiental devido a sua alta reatividade. No entanto, possuem baixa estabilidade química quando expostos ao oxigênio e à água, reduzindo sua eficácia. O objetivo deste trabalho foi desenvolver e validar um método para avaliar a eficiência do nZVI baseado em dois lotes sintéticos L01 e LO2, a partir da degradação de corantes, laranja e violeta de metila (MO e MV). Os testes de degradação anteriores forneceram os melhores resultados para MO $(\sim 100 \%$ de degradação, 12 min de reação, 0,5 $\mathrm{g} \mathrm{L}^{-1}$ de dose). A otimização por planejamento fatorial obteve a condição ótima, $C_{M O}=5,98 \mathrm{~mol} \mathrm{~L}^{-1}$ e $D_{n Z V I}=0,56 \mathrm{~g} \mathrm{~L}^{-1}$. O modelo de Boltzmann ajustou os resultados obtidos $\left(R^{2}=0,993\right)$. Finalmente, foi obtida uma relação matemática que forneceu doses equivalentes de $L 01$ e LO2 em relação ao Padrão. Os ajustes matemáticos aplicados apresentaram $R^{2}>0,99$ e erros $<4 \%$. 


\section{INTRODUCTION}

Nanomaterials emerged as a multidisciplinary technology in the twentieth century and, since then, have gained focus on research, resulting in scientific and technological advances around the world (SHARMA et al., 2017). Nowadays, researches with these materials have being focused on the remediation of contaminants in soil, groundwater and water, resulting in several benefits to the society and environment (LI et al., 2015; PASCHOALINO et al., 2010).

The textile industry is the second biggest polluter of superficial waters, due to the discharge of effluents generated in its manufacturing stages (HOLKAR et al., 2016). This industrial sector consumes a large amount of water, dyes and other chemical components (KAUR et al., 2017). As a result currently, more than 77 thousand tons of dyes per year are leached into industrial effluents, causing their intense coloration, low biodegradability and toxicity (KAUR et al., 2017; PAZ et al., 2017).

Many dyes are recalcitrant compounds, mainly due to their high molecular mass and complex chemical structure, which make them stable when exposed to light, heat and oxidizing compounds (ARCANJO et al., 2018; HOLKAR et al., 2016). Therefore, the development of methods to remove these substances from textile effluents prior to its discharge in superficial waters becomes necessary. In order to solve this problem, chemical, physical and biological methods have been employed, however, they present limitations regarding to cost, efficiency and reaction time (LIN et al., 2012).

In this context, metallic nanoparticles arise as a promising alternative (LIN et al., 2012; QUINA, 2004). For this technological application, several metals such as $\mathrm{Zn}$, Sn, $\mathrm{Pt}, \mathrm{Fe}, \mathrm{Co}$ have been investigated. However, Fe gained notoriety due to its easy production, low cost, besides not having a toxic effect to the environment (OH et al., 2003; PEREIRA et al., 2005; WEI-XIAN ZHANG, 2003). Nanoscale zero-valent iron (nZVI) has several desirable characteristics to degrade some pollutants, such as high surface energy, high reduction capacity and reactivity (LIN et al., 2012; WANG et al., 2015). nZVI presents a reduction potential of $-0.444 \mathrm{~V}$, which is capable to promote the reduction of azo groups existent in many dyes (LI et al., 2015; ZHAO et al., 2014).

The removal of dyes in solution can occur by degradation and/or oxidation by direct or indirect transference of electrons (Equations 1, 2 and 3), transforming them into non-toxic compounds (FU et al., 2014).

$$
\begin{aligned}
& \mathrm{Fe}^{0}+\mathrm{O}_{2}+2 \mathrm{H}^{+} \rightarrow \mathrm{Fe}^{2+}+\mathrm{H}_{2} \mathrm{O}_{2} \\
& \mathrm{Fe}^{0}+\mathrm{H}_{2} \mathrm{O}_{2}+2 \mathrm{H}^{+} \rightarrow \mathrm{Fe}^{2+}+2 \mathrm{H}_{2} \mathrm{O} \\
& \mathrm{Fe}^{0}+\mathrm{H}_{2} \mathrm{O}_{2} \rightarrow \mathrm{Fe}^{3+}+\cdot \mathrm{OH}+\mathrm{OH}^{-}
\end{aligned}
$$

However, nZVI loses reactivity over time, as a consequence of the formation of oxides on its surface during degradation reactions and when exposed to air.(LIN et al., 2012) When nZVI undergoes oxidation to $\mathrm{Fe}^{2+}$ and $\mathrm{Fe}^{3+}$, protons are consumed and hydroxyl ions are produced, consequently, the $\mathrm{pH}$ of the medium increases (CRANE et al., 2012).

As a consequence of the nZVI high reactivity, its stability can be easily compromised, interfering directly on its effectiveness to degrade pollutants. Consequently, it becomes necessary to evaluate this property. Thus, the proposal of this work was to develop a method to evaluate the efficiency of $\mathrm{nZVI}$, taking as a reference its performance on the degradation of two model molecules, the Methyl Orange (MO) and Methyl Violet (MV) dyes.

\section{MATERIALS AND METHODS}

\section{Materials}

The following chemical reagents, obtained from commercial sources, were used in the analyzes: Methyl Orange (Pro Analysi); Methyl Violet (Merck); sodium hydroxide microbeads (Impex, 99\%); glacial acetic acid (Alphatec, 99.7\%); sodium borohydride (NEON, 98,17\%), ethanol (Synth, 99.8\%); ferrous sulfate heptahydrate (Dynamics, 99\%); hydrochloric acid (ALPHATEC, 37\%).

\section{Preparation of solutions}

The acetate/acetic acid buffer solution was prepared from a 0.1 mol L- 1 sodium acetate solution, which had its $\mathrm{pH}$ adjusted to 5 using a 0.1 mol L-1 hydrochloric acid solution. MO and MV stock solutions (1,0 $\square 10-4$ e 3,0 $\square 10-5$ mol L-1, respectively) were prepared and stored under refrigeration at 4 ${ }^{\circ} \mathrm{C}$. All solutions were prepared with ultrapure water, obtained from a Milli-Q® system.

\section{Synthesis of nZVI}

$9.85 \mathrm{~g}$ of ferrous sulfate heptahydrate were added to an Erlenmeyer flask containing $50 \mathrm{~mL}$ of an ethanol / water mixture $(4: 1, v / v)$. The system was stirred on a shaker table (SOLAB SL-180 / A) for 10 minutes. Subsequently, $100 \mathrm{~mL}$ of a freshly prepared sodium borohydride solution (1.08 mol L-1) was slowly dripped into the system, under constant stirring. The mixture was vacuum filtered and then the nanoparticles were washed with water and ethanol. Finally, the material was dried in a rotary evaporator and stored in a flask under refrigeration $\left(\sim 20^{\circ} \mathrm{C}\right)$.

\section{Characterization of nZVI}

In order to determine the particle size distribution and morphology, the synthesized nZVI were characterized by Transmission Electron Microscopy (TEM) using a Tecnai G220 equipment. First, the nZVIs were inserted in ethanol and dispersed by ultrasound. Then the samples were dripped and dried for $24 \mathrm{~h}$ to evaporate the solvent.

\section{General degradation assay}

nZVIs were added in a dye solution $(210 \mathrm{ml})$ at room temperature $\left(\sim 25^{\circ} \mathrm{C}\right)$ and under constant magnetic stirring (SOLAB SL-91). The concentration of the dye in solution, consequently, its removal efficiency (Equation 4), was monitored by UV/Vis Molecular Absorption Spectrophotometry (UV/Vis). In order to this, aliquots $(2 \mathrm{~mL})$ were collected at different time intervals, filtered using 0.45 
$\mu \mathrm{m}$ nitrocellulose membranes and transferred to flasks (10 $\mathrm{mL})$. To standardize the $\mathrm{pH}$ of the samples, $2 \mathrm{~mL}$ of a sodium acetate buffer solution $\left(0.1 \mathrm{~mol} \mathrm{~L}^{-1}, \mathrm{pH} 5\right)$ were added to each flask, and the resulting solutions were analyzed by UV/Vis.

$R=\left(1-\frac{A}{A_{0}}\right) * 100$

Wherein $R$ is the dye removal efficiency. $A$ and $A_{0}$ are absorbance values of the dye solution at the monitored wavelength, in the initial condition (reaction time $=0$ ) and after a certain time of reaction respectively.

The effects of the following parameters were evaluated: (1) nZVI dose: 0.3 and $0.5 \mathrm{~g} \mathrm{~L}^{-1}$, (2) dye initial concentration: $6.0 \times 10^{-5}$ and $2.75 \times 10^{-5} \mathrm{~mol} \mathrm{~L}^{-1}$ and (3) $\mathrm{pH}$ of the medium during reaction: 2,4 and without adjustment. As the $\mathrm{pH}$ of the medium naturally rises during the degradation of the dye, it was kept constant (experiments in $\mathrm{pH} 2$ and 4) throughout the reaction by adding a $0.1 \mathrm{~mol} \mathrm{~L}^{-1}$ hydrochloric acid solution. These same conditions were applied on the experiments with $\mathrm{MO}$ and MV, which were performed in duplicate.

\section{UV/Vis Molecular Absorption Spectrophotometry Analyzes}

As mentioned before, the concentrations of $\mathrm{MO}$ and MV in solution were monitored by UV/Vis. As these dyes change color according to the $\mathrm{pH}$ of the medium, the $\mathrm{pH}$ of analysis was standardized. For this, borate $(\mathrm{pKa}=9.14)$ and acetate $(\mathrm{pKa}=4.76)$ buffer solutions $\left(0.1 \mathrm{~mol} \mathrm{~L}^{-1}\right)$ were tested, being the latter selected to be used on the assays (the justification is detailed in the Results section). Therefore, prior to the analyzes, the buffer solution was added to each aliquot (volume ratio 1:1). The absorbance values were monitored at the wavelength of $465 \mathrm{~nm}$ and $585 \mathrm{~nm}$ for the MO and MV dyes respectively.

MO and MV analytical curves were constructed in the concentration ranges of $1.0 \times 10^{-4}$ to $1.0 \times 10^{-6} \mathrm{~mol} \mathrm{~L}^{-1}$ and $3.0 \times 10^{-5}$ to $1.0 \times 10^{-7} \mathrm{~mol} \mathrm{\textrm {L } ^ { - 1 }}$, respectively. The limits of detection (LOD) and quantification (LOQ) of the method were estimated using the Equations 5 and 6.

$\mathrm{LOD}=3,3 \times \mathrm{s} / \mathrm{b}$

$\mathrm{LOQ}=10 \times \mathrm{s} / \mathrm{b}$

Wherein $s$ is the standard deviation estimator of the blank readings and $b$ is the angular coefficient of the analytical curve.

\section{Optimization of the dye degradation by a factorial planning}

The optimization of the MO degradation was performed by a $2^{2}$ factorial planning with a central point (Table 1 ), considering the MO initial concentration and the nZVI dose as independent variables, and the MO removal efficiency as the depedent variable. The reactions were conducted within a 6 min interval, in which aliquots were withdrawn each minute, to obtain the kinetic behaviour of the process. The MO removal achieved in 2 minutes of reaction was chosen as the response of the planning, because the dye had not been completely degraded yet at this point. All experiments were performed in duplicate.

\section{Construction of a mathematical model to predict equivalent doses of $\mathrm{nZVI}$}

In order to construct a mathematical model to predict equivalent doses of nZVIs from different synthetic lots that result in a same removal efficiency value, a new assay was performed. By the evaluation of the response surface obtained on the optimization, the working initial concentration of the dye $\left(6.00 \times 10^{-5} \mathrm{~mol} \mathrm{~L}^{-1}\right)$ and time reaction $(2 \mathrm{~min})$ was selected. Thus, different masses of nZVI from a standard lot (SL) were added to MO solutions ( $210 \mathrm{~mL})$, without $\mathrm{pH}$ adjustment, at 25 ${ }^{\circ} \mathrm{C}$ and under constant stirring, in order to obtain the following nZVI doses: $0.25 ; 0.35 ; 0.45 ; 0.50 ; 0.65 ; 0.80 ; 1.00 \mathrm{~g} \mathrm{~L}^{-1}$. From the data obtained on the experiments, a model was constructed with the aid of the OriginPro 8.5 software, in which a mathematical function that best described the relation between nZVI dose and MO removal efficiency was determined. The fit quality of the model to the data was evaluated by the correlation coefficient and the residue graph.

Table $1.2^{2}$ factorial planning with central point performed to evaluate the effects of the MO initial concentration and nZVI dose on the degradation of MO by nZVI. Experimental conditions: $\mathbf{p H}$ without adjustment; $\mathrm{V}=\mathbf{2 1 0}$ $\mathrm{mL} ; \mathrm{T} \sim 25^{\circ} \mathrm{C}$.

$\begin{array}{ccc}\text { Experiment } & \begin{array}{c}\text { MO Initial Concentration } \\ \left(\mathrm{mol} \mathrm{L}^{-1}\right)\end{array} & \begin{array}{c}\text { nZVI Dose } \\ \left(\mathrm{g} \mathrm{L}^{-1}\right)\end{array} \\ 1 & +\left(7.0 \times 10^{-5}\right) & +(0.6) \\ 2 & +\left(7.0 \times 10^{-5}\right) & -(0.4) \\ 3 & -\left(5.0 \times 10^{-5}\right) & +(0.6) \\ 4 & -\left(5.0 \times 10^{-5}\right) & -(0.4) \\ 5 & 0\left(6.0 \times 10^{-5}\right) & 0(0.5)\end{array}$

\section{Method Validation}

In order to validate the model, two lots of nZVI (L1 and L2) were synthesized and used on MO degradation assays. These assays were performed under the same conditions as the ones with the nZVI from the standard lot (SL). The nZVI dose applied on the assays was arbitrarily selected. From the results, using the OriginPro 8.5 software, graphs relating MO removal with doses of nZVI from L1 and L2 were plotted in order to analyze the behavior of both systems and determine a mathematical relation between these variables (supplementary material).

Thus, experimental doses of nZVI from SL were compared with theoretical doses from L1 and L2 that would result in a same MO removal efficiency value. These theoretical nZVI doses were determined by entering the MO removal efficiency values achieved on the assays using nZVI from SL in mathematical functions relating the MO removal with nZVI (from L1 or L2) dose. Thus, the fit quality of the model to the data was evaluated by an analysis of the relative error, calculated using the Equation 7:

Relative Error $=\frac{\mid \text { Standard Dose }- \text { Theoretical Dose } \mid}{\text { Standard Dose }} \times 100$

\section{RESULTS AND DISCUSSION}

\section{Characterization of nZVIs}

Morphological studies of the nZVIs from SL were performed by Scanning Electron Microscopy (SEM), the obtained micrographs are presented in the supplementary material (Figure 1S). It can be seen that the nZVIs have 
nanometric dimensions $(<100 \mathrm{~nm})$ and spherical format (Figure 1S). In addition, the formation of agglomerates also can be observed, which, according to SHIH et al. (2011), (SHIH; HSU; SU, 2011) is derived from inner magnetic interactions between iron particles themselves.

\section{Conditions of analysis}

UV-Visible absorption spectra of solutions containing the model molecule (MO or MV) in different concentrations at pH 5.5 are presented in Figure 1. Both molecules present a main characteristic absorbance band in the visible region, which corresponds to $\lambda$ máx $=465 \mathrm{~nm}$ for the $\mathrm{MO}$ and $\lambda$ máx $=$ $585 \mathrm{~nm}$ for the MV.

MO $(\mathrm{pKa}=3.45)$ presents the following colors according to the $\mathrm{pH}$, red $(\mathrm{pH}<3.1)$, orange $(3.1<\mathrm{pH}<4.4)$ and yellow ( $\mathrm{pH}>4.4)$ (ZHAI et al., 2018). In its turn, MV presents green $(\mathrm{pKa}=1.15$ and $\mathrm{pH} \leq 1)$, blue $(\mathrm{pKa}=2$ and $\mathrm{pH} \approx 2)$ and violet $(\mathrm{pH} \approx 7)$ colors(ADAMS; ROSENSTBIN, 1914). Considering the degradation process undergo $\mathrm{pH}$ change, it is necessary to standardize the $\mathrm{pH}$ of the dye solutions to perform the UV-Visible spectroscopy analysis.

Therefore, buffer solutions were added to the samples (volume ratio 1:1) prior to the analyses. Two buffer solutions

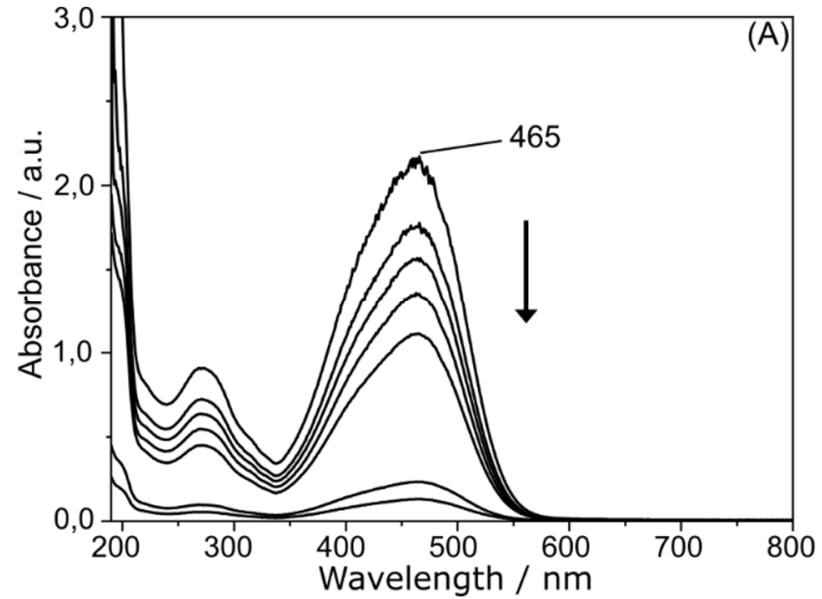

were tested: borate $(\mathrm{pKa}=9.24, \mathrm{pH} 9)$ and acetate $(\mathrm{pKa}=$ 4.76, $\mathrm{pH} 5$ ), both at the concentration of $0.1 \mathrm{~mol} \mathrm{~L}^{-1}$. The tests were carried out with these buffer solutions to verify which one would present sufficient buffering power to maintain the $\mathrm{pH}$ of the solutions constant and, consequently, avoid the alteration of the characteristic absorption bands of the dye solutions.

The addition of the borate solution to the samples resulted on the formation of precipitates, which interfered in the analyzes, confirming oxy-reductive processes are involved in the observed color removal. According to WENG et al. (2014) e ZHAO et al. (2014), o Fe0 is oxidized to $\mathrm{Fe}^{2+}$ and $\mathrm{Fe}^{3+}$, which may form hydroxy complexes depending on the $\mathrm{pH}$ value. Thus, when the $\mathrm{pH}$ is adjusted by the borate buffer, $\mathrm{Fe}(\mathrm{OH})_{3}$ and $\mathrm{Fe}(\mathrm{OH})_{4}^{-}$complexes are formed, which can be confirmed by the evaluation of the iron species distribution (Figure 2S). Therefore, it can be inferred that the iron complexes in solution were formed, which adsorved the dye and the degradation products. Therefore, the acetate buffer solution was selected to adjust the $\mathrm{pH}$ of the samples for the analyses.

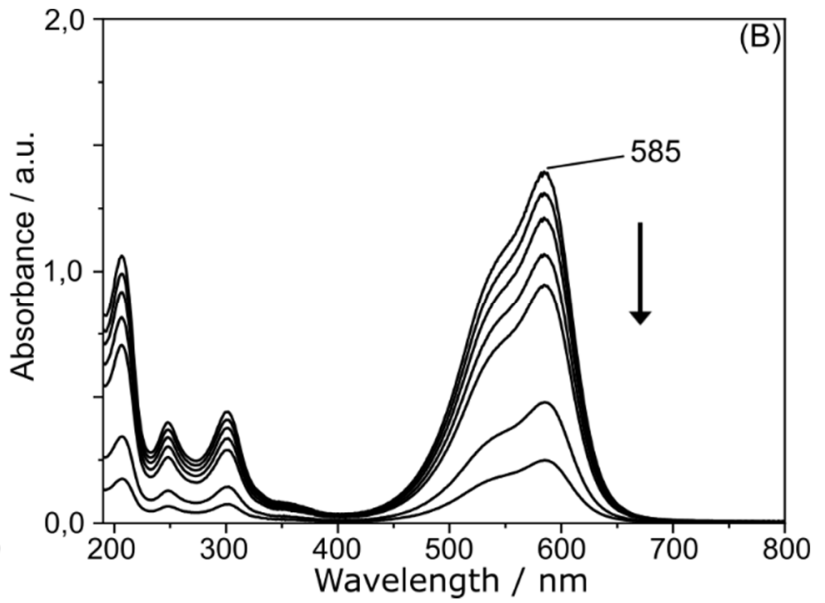

Figure 1. UV/Vis Molecular Absorption Spectra as a function of the concentration of (a) Methyl Orange and (b) Methyl Violet in solution at pH 5.5
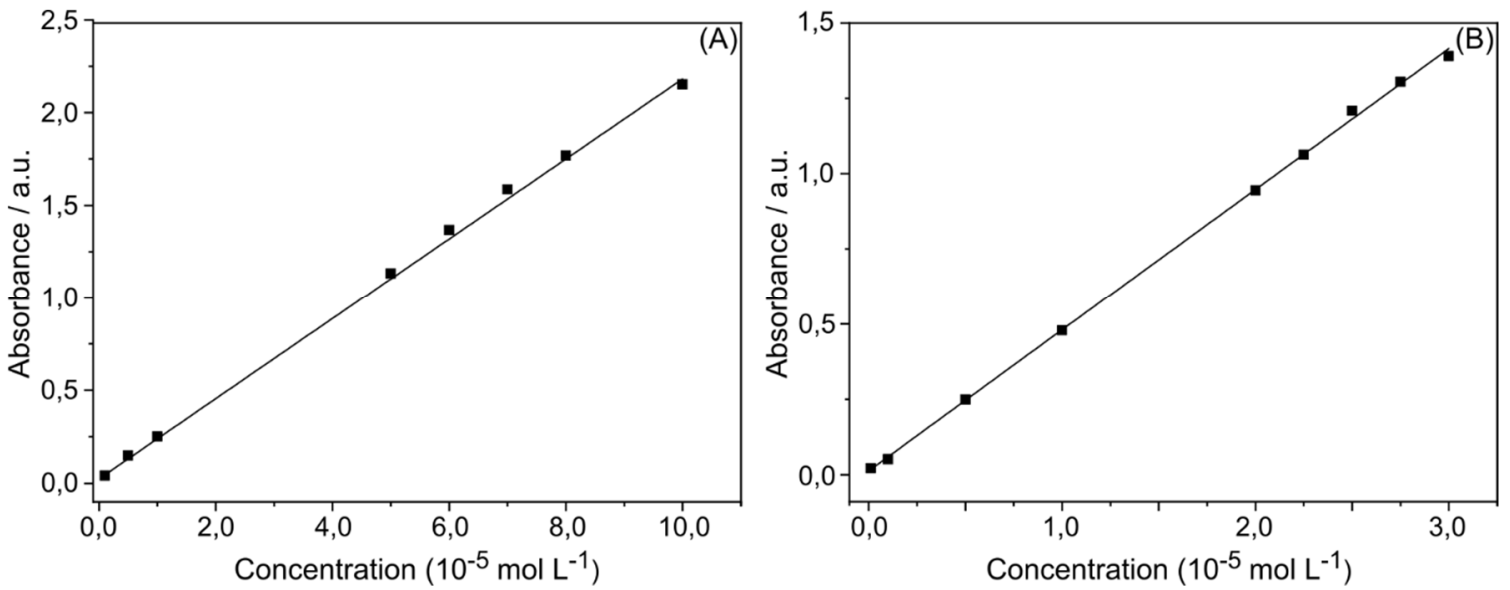

Figure 2. Analytical curves obtained from the UV/Vis Molecular Absorption Spectrophotometry analysis: (a) Methyl Orange (b) Methyl Violet. Experimental conditions: $\mathrm{pH}=5$, room temperature $\left(\sim 25^{\circ} \mathrm{C}\right)$, buffered system $\left(0.1 \mathrm{~mol} \mathrm{~L}^{-1}\right.$ acetate buffer). 


\section{Construction of the analytical curve}

Once established the experimental conditions, analytical curves (Figure 2) were constructed for MO $\left(1.0 \times 10^{-4}\right.$ a $1.0 \times 10^{-}$ $\left.{ }^{6} \mathrm{~mol} \mathrm{~L}^{-1}\right)$ and $\mathrm{MV}\left(3.0 \times 10^{-5}\right.$ a $\left.1.0 \times 10^{-7} \mathrm{~mol} \mathrm{~L}^{-1}\right)$, considering the absorbance values at the main characteristic band ( $\lambda$ máx). The fit quality of the linear model was evaluated using the determination coefficients $\left(\mathrm{R}^{2}\right)$, which were higher than 0.999 for both dyes. The values were 0.9988 and 0.9993 for MO and MV, respectively (Figure 2). The estimated LOD and LOQ of the method are presented in Table 2.

Table 2. Estimated detection and quantification limits for model dyes according to the data obtained by the analytical curve.

$\begin{array}{ccc}\text { Analyte } & \begin{array}{c}\text { Detection Limit } \\ \left(\mathrm{mol} \mathrm{L}^{-1}\right)\end{array} & \begin{array}{c}\text { Quantification Limit } \\ \left(\mathrm{mol} \mathrm{L}^{-1}\right)\end{array} \\ \text { MO } & 5,40 \times 10^{-9} & 1,74 \times 10^{-8} \\ \text { MV } & 8,28 \times 10^{-10} & 2,51 \times 10^{-9}\end{array}$

In order to validate the method to evaluate the efficiency of nZVIs, MO and MV initial concentrations at the degradation assays were selected, corresponding to $6.0 \times 10^{-5} \mathrm{e}$ $2.75 \times 10^{-5} \mathrm{~mol} \mathrm{~L} \mathrm{~L}^{-1}$, respectively. These concentration values were selected because they are located in the central region of the curves (Figure 2), resulting in smaller analytical errors. This precaution was taken in order not to extrapolate the upper and lower limits of detection (LOD) of the equipment and avoid the formation of noise in the spectra.

\section{Study of the dose of NZVIs}

Degradation assays of the model molecules (MO and MV) were performed to evaluate the efficiency of the nZVIs and establish a working dose that would make it possible to monitor the degradation kinetics. The results are shown in Figure 3.

A removal efficiency of $\sim 100 \%$ was observed at the first 12 min for nZVIs doses of 0.5 and $0.3 \mathrm{~g} \mathrm{~L}^{-1}$, whereas for a dose of $0.2 \mathrm{~g} \mathrm{~L}^{-1}$, the removal efficiency was less than $60 \%$. This confirms that the degradation process is strongly dependent on the nZVI dose, which, when increased, results in a higher availability of reactive sites, therefore, favoring the process.

Initially, an nZVI dose of $0.5 \mathrm{~g} \mathrm{~L}^{-1}$ was tested to evaluate the degradation of the model molecules. For MO, this dose made it possible to evaluate the reaction kinetics over time (Figure 3). However, for MV, the degradation process occurred rapidly (less than $1 \mathrm{~min}$ ), therefore, the results are not presented in Figure 3. Thus, it was necessary to decrease the nZVI dose, values of 0.2 and $0.3 \mathrm{~g} \mathrm{~L}^{-1}$ were tested, being the latter selected because it allowed the monitoring of the reaction kinetics over time by UV/Vis MAS.

The occurrence of degradation process was confirmed by the spectra obtained throughout the reaction (Figure $3 \mathrm{~S}$ and $4 \mathrm{~S})$. For MO, a peak appears in the region of $245 \mathrm{~nm}$, which intensifies as the reaction occurs (independently of the $\mathrm{pH}$ value). As described by LI et al. (2015), this might correspond to the presence of aniline, a possible degradation product of the reaction formed by the cleavage of the chromophore group (-N
$=\mathrm{N}-$ ) of the the dye.

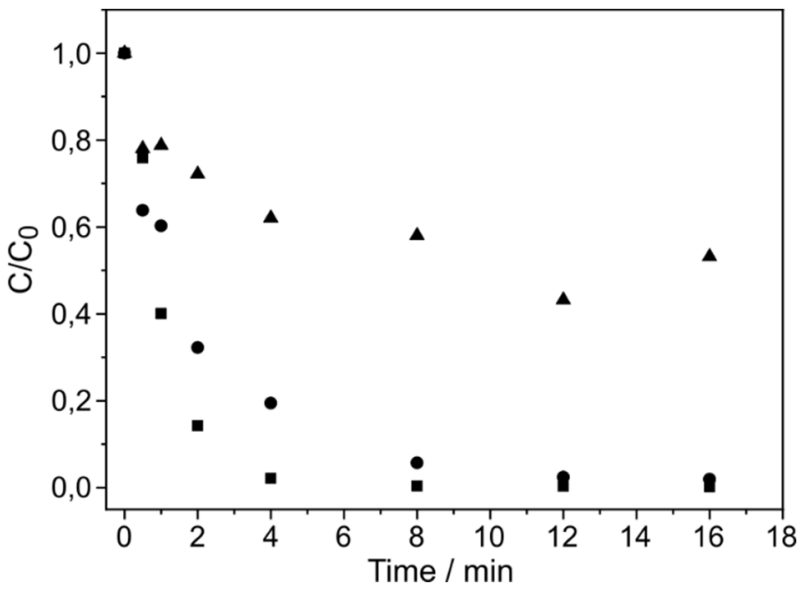

Figure 3. Dose study for dyes models. Experimental conditions: $[\mathrm{MO}]=6 \times 10^{-5} \mathrm{~mol} \mathrm{~L}^{-1},[\mathrm{MV}]=2.75 \times 10^{-5} \mathrm{~mol}$ $\mathrm{L}^{-1}$; $\mathrm{nZVI}$ doses $=0.5 \mathrm{~g} \mathrm{~L}^{-1}, 0.2$ and $0.3 \mathrm{~g} \mathrm{~L}^{-1} ; \mathrm{V}=210 \mathrm{~mL}$; room temperature $\left(\sim 25^{\circ} \mathrm{C}\right) ; \Delta$ dose $0,2 \mathrm{~g} \mathrm{~L} \mathrm{~L}^{-1}, \bullet$ dose $0,3 \mathrm{~g}$ $\mathrm{L}^{-1}$, dose $0,5 \mathrm{~g} \mathrm{~L}^{-1}$.

The degradation process (peak appearance at $375 \mathrm{~nm}$ ) is also observed for MV, but it only occurred at $\mathrm{pH} 2$. BHATTACHARJEE et al. (2016) mention that the formation of compounds such as aldehyde, carboxylic acid, p-rosaniline and phenol may occur during the degradation process of this dye.

\section{Effect of pH}

First, it is worth mentioning that when the nZVIs are added to the medium, the initial $\mathrm{pH}(\sim 5.5)$ of the solution naturally rises to approximately 8.5 and stabilizes, making it necessary to evaluate different $\mathrm{pH}$ conditions for the system under study.

The influence of the $\mathrm{pH}$ on the degradation of $\mathrm{MO}$ and MV by nZVI is shown in Figure 3. For MO, it becomes clear that the kinetic rate (reaction time $<2$ min) decreases as the $\mathrm{pH}$ increases (Figure 3, a). However, after three minutes of reaction, the color removal efficiencies at different $\mathrm{pH}$ values are approximately the same. According to ZHAO et al. (2014), at an acidic $\mathrm{pH}, \mathrm{Fe}^{0}$ surface becomes more available, favoring the reductive process, whereas in basic conditions, an oxide layer difficult the access to reactive sites. This oxide layer formed during the reaction reduces the reactivity of the nZVIs, assigning an exponential profile to the kinetic curve, as presented in Figure 3.(WENG et al., 2014)

The $\mathrm{pH}$ also influences the kinetic rate of the MV removal (Figure 3, b). However, high error values were observed. Therefore, as this experiment presented poor reproducibility, only the MO was selected to be used on the following assays performed to develop and validate the model.

Although the MO degradation kinetics was favored at more acidic $\mathrm{pH}$ conditions, the subsequent assays were performed without $\mathrm{pH}$ adjustment, because it was more economical and simpler to execute. 


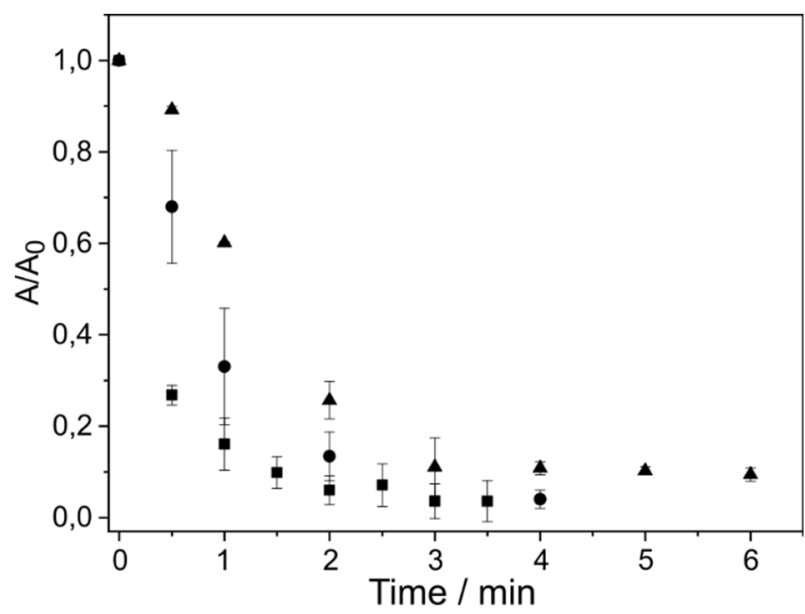

Figure 4. Removal efficiency of methyl orange. Experimental conditions: $[\mathrm{MO}]_{0}=6.00 \times 10^{-5} \mathrm{~mol} \mathrm{~L}^{-1} ; \mathrm{nZVI}$ dose $=0.5 \mathrm{~g} \mathrm{~L}^{-1}(\mathrm{MO}) ; \mathrm{V}=210 \mathrm{~mL}$; Room temperature $\left(\sim 25^{\circ} \mathrm{C}\right)$; pH 2, 4 and without adjustment (pHO of the dye solutions $\sim 5.5$ ); $\triangle$ pH without adjustment, $\bullet$ pH 4; - pH 2.

\section{Factorial Planning $2^{2}$ with Central Point}

The influence of the MO initial concentration and the nZVI dose on the MO removal efficiency was evaluated by a $2^{2}$ Factorial Planning with Central Point (Figure 5).

The results demonstrate that these variables influence the kinetic rate. In fact, raising the $\mathrm{MO}$ initial concentration reduces the kinetic rate, as well as increasing the nZVI dose favors degradation. Both are justified by the same theory, the collision between the dye molecules with the reactive surface of the nZVIs, (SHU et al., 2010) in which they follow the relationship explained above.

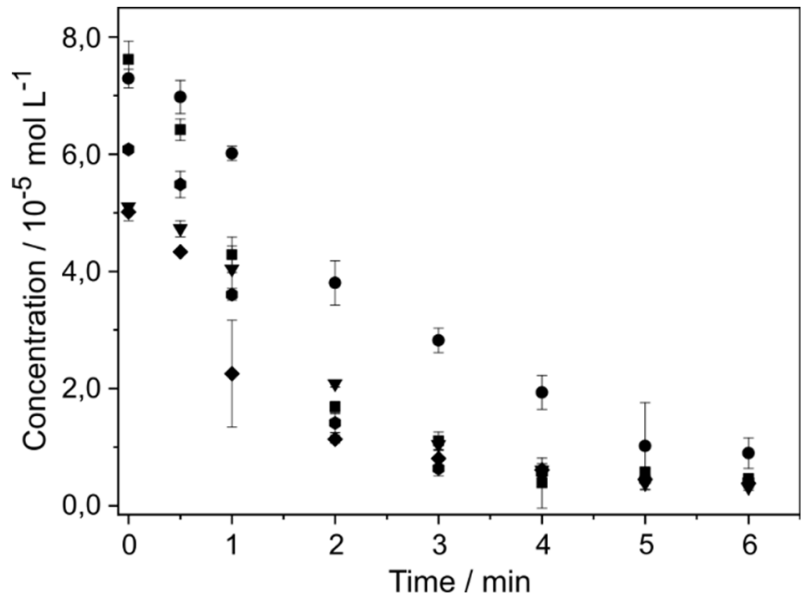

Figure 5. Factorial planning of the methyl orange degradation reaction by $\mathrm{nZVI}$, without $\mathrm{pH}$ adjustment of the medium. Experimental conditions: Reaction time: 6 min; Reaction volume: $210 \mathrm{~mL}$; Room temperature $(\sim 25$ ${ }^{\circ}$ C); - Experiment 1, $\bullet$ Experiment 2, $\bullet$ Experiment 3, V Experiment 4, Experiment 5.

The removal efficiency at 2 min of reaction was defined as the dependent variable of the factorial planning, since the system did not reach an equilibrium and/or $100 \% \mathrm{MO}$ degradation within the time interval adopted in the experiments (6 min). The results were analysed using the STATSOFT STATISTICA 7.0.61.0 software by an Analysis of Variance ANOVA (Table 3).
The linear (L) and quadratic (Q) effects of the nZVI dose and MO initial concentration factors, as well as their interaction, are shown by the ANOVA results (Table 3). At a significance level of 0.05 , the following factors were significant on the MO removal: nZVI (L), nZVI (Q) and the interaction between nZVI dose (L) and MO initial concentration $(\mathrm{L})$.

The obtained response surface (Figure 6) indicates an optimum condition for the MO removal. The data presented good adjustments $\left(\mathrm{R}^{2}=0.9886\right)$ to the mathematical model in the studied experimental domain.

A mathematical model that correlates the variables (MO initial concentration and nZVI dose) with the MO removal is presented in Equation 8. Where $R$ is the MO removal (\%), $C_{M O}$ is the MO initial concentration $\left(\mathrm{mol} \mathrm{L}^{-1}\right)$ and $D_{N P}$ is the nZVI dose $\left(\mathrm{g} \mathrm{L}^{-1}\right)$.

$R=193.36-1.28 C_{M O}-1.45 C_{M O}^{2}+974.38 D_{N P}-$
$1029.29 D_{N P}^{2}+28.83 C_{M O} . D_{N P}$

In order to ascertain the critical points, the Lagrange criterion and the Hessian determinant were used in Equation 6. Thus, $\operatorname{det}[\mathrm{H}]=-0.282$ and $\frac{\partial^{2} R}{\partial^{2} D_{N P}}=-2.90$, referring to a maximum point (FERREIRA, 2004). The critical point of the response surface is $C_{M O}=5.98 \mathrm{~mol} \mathrm{~L}^{-1}$ and $D_{N P}=$ $0.56 g L^{-1}$.

Fitted Surface; Variable: Removal (\%)

2 factors, 1 Blocks, 10 Runs; MS Residual=4,46 DV: Removal (\%)

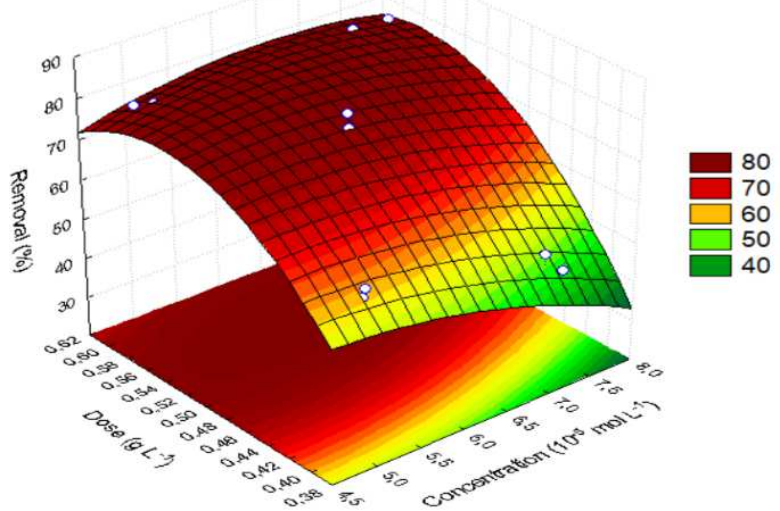

Figure 6. Response surface obtained from the factorial planning. Independent variables: $n Z V I$ dose $\left(g^{-1}\right)$ and MO initial concentration $\left(\mathrm{mol} \mathrm{L}^{-1}\right)$, dependent variable (response): MO removal efficiency $(\%)$.

\section{Obtaining the nZVI dose for the mathematical model}

From the interpretation of the results obtained in the factorial planning, the following experimental conditions were adopted: MO initial concentration of $6.00 \times 10^{-5} \mathrm{~mol} \mathrm{~L}^{-1}$, nZVI dose varying from 0 to $1.00 \mathrm{~g} \mathrm{~L}^{-1}$ and $\mathrm{pH}$ without adjustment. The nZVI dose and MO initial concentration values were chosen so that the points approached the optimum condition of MO removal for the system. The obtained data were adjusted to a Boltzmann's Sigmoidal nonlinear regression model relating MO removal with nZVI dose (Figure 7). The proposed model presented a good fit to the experimental data $\left(\mathrm{R}^{2}=\right.$ 0.9999), which is given by Equation 9. 
Table 3. ANOVA results of the factorial planning.

\begin{tabular}{|c|c|c|c|c|c|}
\hline Factor & $\begin{array}{c}\text { Quadratic } \\
\text { Sum }\end{array}$ & $\begin{array}{l}\text { Degrees of } \\
\text { Freedom }\end{array}$ & $\begin{array}{l}\text { Average } \\
\text { Quadratic }\end{array}$ & Statistics F & p-value \\
\hline $\begin{array}{l}\text { (1) Concentration } \\
\left(10^{-5} \mathrm{~mol} \mathrm{~L}^{-1}\right)(\mathrm{L})\end{array}$ & 7,298 & 1 & 7,2984 & 1,6371 & 0,2699 \\
\hline $\begin{array}{c}\text { Concentration } \\
\left(10^{-5} \mathrm{~mol} \mathrm{~L}^{-1}\right)(\mathrm{Q})\end{array}$ & 1,888 & 1 & 1,8879 & 0,4235 & 0,5507 \\
\hline $\begin{array}{c}\text { (2) Dose }\left(\mathrm{g} \mathrm{L}^{-1}\right) \\
\text { (L) }\end{array}$ & 756,975 & 1 & 756,975 & 169,793 & 0,0002 \\
\hline Dose $\left(\mathrm{g} \mathrm{L}^{-1}\right)(\mathrm{Q})$ & 35,821 & 1 & 35,8206 & 8,0347 & 0,0471 \\
\hline $\begin{array}{l}\text { Interaction }(1 \mathrm{~L}) \\
\text { with }(2 \mathrm{~L})\end{array}$ & 78,061 & 1 & 78,0608 & 17,5093 & 0,0139 \\
\hline Error & 17,833 & 4 & 4,4582 & & \\
\hline Total SQ & 1561,679 & 9 & & & \\
\hline
\end{tabular}
$\left(\mathrm{g} \mathrm{L}^{-1}\right)$.

Where, $R$ is MO removal (\%) and $D_{N P}$ is the nZVI dose

$\% R=89,8029+\frac{-5,7575-89,8029}{1+e^{\frac{D_{N P}-0,2767}{0,1005}}}$

Analyzing the graph shown in Figure 7, it can be inferred that from a dose of $0.5 \mathrm{~g} \mathrm{~L}^{-1}$ (inflection point) the MO removal reaches a plateau (maximum value).

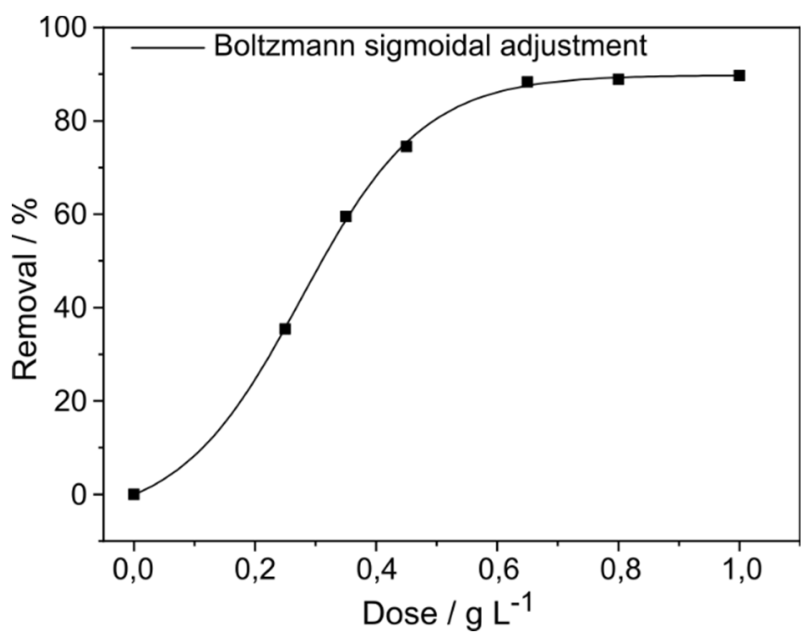

Figure 7. MO removal as a function of the nZVI (Standard Lot) dose.

In addition to the $\mathrm{R}^{2}$ analysis, a residue chart (Figure 5S) was developed to evaluate the quality of fit. As can be seen, the points occur randomly and homogeneously around the horizontal axis (MO removal $=0)$, taking into account the basic premise of ANOVA, where the behavior of the residue variance is constant. Thus, it can be concluded that the data are not vitiated, indicating adequacy to the proposed Boltzmann's Sigmoidal model.

\section{Method Validation}

In order to validate the model that predicts the nZVI dose needed to achieve a certain removal value, two lots, L1 and L2, were synthesized. Degradation tests using this material were performed (Figure 6S), as previously proposed. As expected, the results of MO removal efficiencies were different between L1 and L2. The parameters studied resulted in satisfactory responses to Boltzmann's Sigmoidal non-linear regression, which are described by Equations $1 \mathrm{~S}$ and $2 \mathrm{~S}$ (Supplementary Material). The adjustments exhibit high values for the coefficients of determination $\left(\mathrm{R}^{2}\right)$, being 0.9955 and 0.9941 for L1 and L2, respectively.

To evaluate if the adjustments were adequate, residue graphs (Figure 7S) were elaborated. It can be seen that the data are distributed randomly along the entire zero line, with no discrepancy and/or trend between the points, indicating its adequacy.

In order to correlate the nZVI dose from the standard Lot (SL) with the ones from L1 and L2, a mathematical relationship between them was determined (Figure 8). These proposed correlations presented a satisfactory behavior since the coefficients of determination $\left(\mathrm{R}^{2}\right)$ were 0.9989 and 0.9966 for L1 and L2, respectively.

The residue graphs for the adjustments are presented in the supplementary material (Figure 1s). It is possible to visualize that the data is distributed along the entire zero line, with no discrepant points, indicating the reliability of the adjustments.

The adjustments provide an allometric (Equation 10) and a logarithmic (Equation 11) models for L1 and L2, respectively.

$y=0,25 x^{0,5466}$

$y=0,2715+0,0861 \ln (x)$

Where $y$ is the dose from the SL dose and $x$ is the dose from L1 (Equation 10) or L2 (Equation 11).

By using Equations 9 and 10, relative errors were 
calculated in relation to the theoretical doses and the dose from the SL used in the MO degradation assay to validate the method (Table 4).

It can be inferred that the data obtained good precision and accuracy in conforming to the applied model. This confirms that the experiments can be reproduced with good

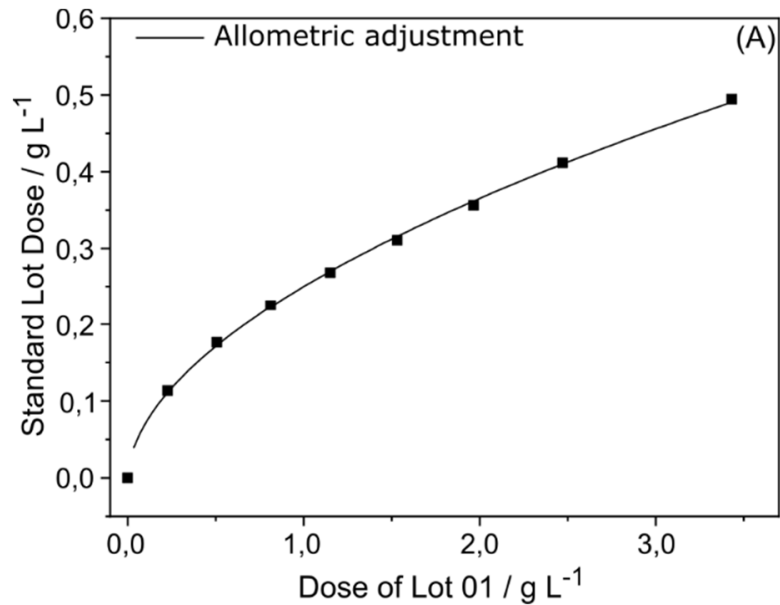

agreement between the experimental and theoretical data.

Applying Equations 10 and 11, it is possible to perform the necessary corrections on L1 and L2 doses to obtain the same removal efficiency as the one using nZVI from the SL, provided that the same experimental conditions are maintained.

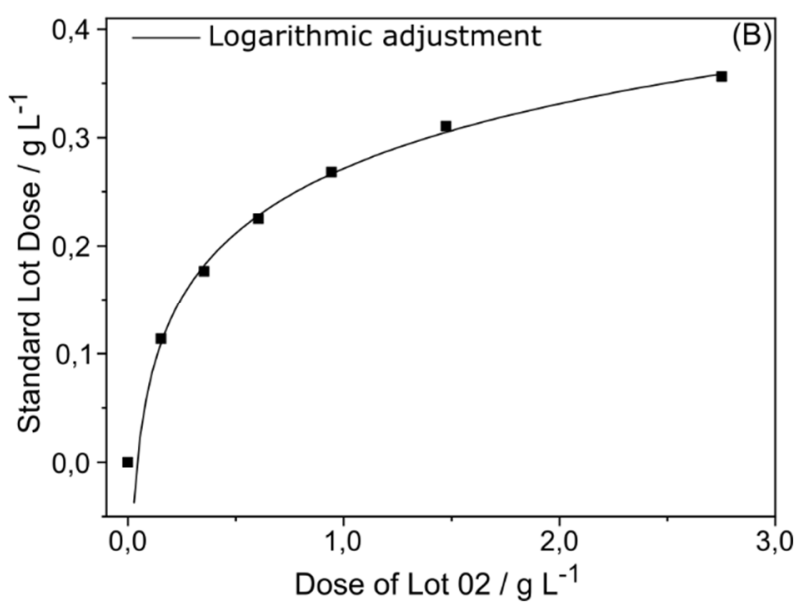

Figure 8. Adjustment between the nZVI dose from the standard lot (SL) with that from: (a) Lot 1 (L1) and (b) Lot 2 (L2). Experimental conditions: CO (MO): $6.00 \times 10^{-5} \mathrm{~mol} \mathrm{~L}^{-1}$; Volume of the solution $=50 \mathrm{~mL}$; Room temperature $\left(\sim 25{ }^{\circ} \mathrm{C}\right)$.

Table 4. Relative error between doses of Lot 1 and 2

\begin{tabular}{ccc} 
& Lot 1 & \\
\hline $\begin{array}{c}\text { Standard Dose } \\
\left(\mathrm{g} \mathrm{L}^{-1}\right)\end{array}$ & $\begin{array}{c}\text { Theoretical Dose } \\
\left(\mathrm{g} \mathrm{L}^{-1}\right)\end{array}$ & Relative error $(\%)$ \\
0 & 0 & 0 \\
0.1137 & 0.1113 & 2.1409 \\
0.1765 & 0.1723 & 2.3712 \\
0.2250 & 0.2231 & 0.8369 \\
0.2682 & 0.2700 & 0.6667 \\
0.3106 & 0.3156 & 1.6106 \\
0.3562 & 0.3617 & 1.545 \\
0.4115 & 0.4099 & 0.3896 \\
0.4946 & 0.4905 & 0.8266 \\
\hline
\end{tabular}

\section{CONCLUSION}

Nanoscale zero-valent iron (nZVI) presented high efficiency (above $75 \%$ ) on the degradation of the methyl orange (MO) and methyl violet (MV) dyes. However, the experiments with MV presented low reproducibility, therefore, the proposed method used the MO as a reference pollutant.

The MO degradation process is strongly influenced by the factors nZVI dose (linear and quadratic) and its interaction with MO initial concentration (linear). An optimal condition for MO removal by nZVI was determined by the factorial planning $\left(C_{M O}=5.98 \mathrm{~mol} \mathrm{~L} L^{-1}, D_{N P}=0.56 \mathrm{~g} \mathrm{~L}^{-1}\right)$. It was possible to obtain a model that predicts the MO removal basing on the MO initial concentration and nZVI dose, which presented a good fit to the experimental data $\left(\mathrm{R}^{2}=0.9886\right)$.

\section{Lot 2}

Standard Dose

$\left(\mathrm{g} \mathrm{L}^{-1}\right)$

0

0.1137

0.1765

0.2250

0.2682

0.3106

0.3562
Theoretical Dose ( $\left.\mathrm{g} \mathrm{L}^{-1}\right)$

0

0.1103

0.1818

0.2281

0.2665

0.305

0.3587
Relative error (\%)

0

3.0290

2.9869

1.3607

0.6162

1.8185

0.6928
The MO removal in function of the nZVI dose for a fixed MO initial concentration $\left(6.00 \times 10^{-5} \mathrm{~mol} \mathrm{~L}^{-1}\right)$ was adjusted to Boltzmann's Sigmoidal nonlinear models, with $\mathrm{R}^{2}$ $=0.9999,0.9955$ and 0.9941 for the Standard Lot $(\mathrm{SL})$, Lot 1 (L1) and Lot 2 (L2), respectively.

Thus, it was possible to propose a mathematical method to correlate doses of nZVI from different lots (L1 and L2) with the one from a standard lot (SL) that resulted in a same MO removal efficieny. The method was validated by an allometric $\left(\mathrm{R}^{2}=0.9989\right)$ and a logarithm $\left(\mathrm{R}^{2}=0.9966\right)$ mathematical adjustments for L1 and L2, respectively.

Finally, therefore, through mathematical adjustments, it was possible to obtain equivalent doses of nZVI from different synthetic lots that result in the same removal efficiency of a certain pollutant. 


\section{ACKNOWLEDGMENTS}

The authors are grateful to the Brazilian Agency CAPES, CNPq and FAPEMIG for financial support. We also acknowledge the Center of Microscopy at the Universidade Federal de Minas Gerais (http://www.microscopia.ufmg.br) for providing the equipment and technical support for experiments involving electron microscopy.

\section{SUPPLEMENTARY MATERIAL}

Figures $1 \mathrm{~S}$ to $8 \mathrm{~S}$ and Equations $1 \mathrm{~S}$ to $2 \mathrm{~S}$ can be found at https://periodicos.ufv.br/ojs/jcec/ in PDF format, with free access.

\section{R E F E R E N C E S}

ADAMS, E. Q.; ROSENSTBIN, L. The color and ionization of crystal-violet. Journal of the American Chemical Society, v. 36, n. 7, p. 1452-1473, 1914.

ARCANJO, G. S. et al. Heterogeneous photocatalysis using $\mathrm{TiO} 2$ modified with hydrotalcite and iron oxide under UV-visible irradiation for color and toxicity reduction in secondary textile mill effluent. Journal of Environmental Management, v. 211, p. 154-163, 2018

BHATTACHARJEE, A. et al. Photodegradation of methyl violet $6 \mathrm{~B}$ and methylene blue using tin-oxide nanoparticles (synthesized via a green route). Journal of Photochemistry and Photobiology A: Chemistry, v. 325, p. 116-124, jul. 2016.

CRANE, R. A.; SCOTT, T. B. Nanoscale zero-valent iron: Future prospects for an emerging water treatment technology. Journal of Hazardous Materials, v. 211212, p. 112-125, abr. 2012.

FERREIRA, S. Doehlert matrix: a chemometric tool for analytical chemistry-review. Talanta, v. 63, n. 4, p. 1061-1067, jul. 2004.

FU, F.; DIONYSIOU, D. D.; LIU, H. The use of zero-valent iron for groundwater remediation and wastewater treatment: A review. Journal of Hazardous Materials, v. 267, p. 194-205, 2014.

HOLKAR, C. R. et al. A critical review on textile wastewater treatments: Possible approaches. Journal of Environmental Management, v. 182, p. 351-366, 2016

KAUR, P.; KUSHWAHA, J. P.; SANGAL, V. K. Evaluation and disposability study of actual textile wastewater treatment by electro-oxidation method using $\mathrm{Ti} / \mathrm{RuO} 2$ anode. Process Safety and Environmental Protection, v. 111, p. 13-22, 2017.

LI, P. et al. Enhanced decolorization of methyl orange using zero-valent copper nanoparticles under assistance of hydrodynamic cavitation. Ultrasonics Sonochemistry, v. 22, p. 132-138, 2015.

LIN, Y. et al. Degradation of scarlet 4BS in aqueous solution using bimetallic $\mathrm{Fe} / \mathrm{Ni}$ nanoparticles. Journal of Colloid and Interface Science, v. 381, n. 1, p. 30-35, 2012.

$\mathrm{OH}, \mathrm{S}$. Y. et al. Enhancing Fenton oxidation of TNT and RDX through pretreatment with zero-valent iron. Water Research, v. 37, n. 17, p. 4275-4283, 2003.

PASCHOALINO, M. P.; MARCONE, G. P. S.; JARDIM, W.
F. Os nanomateriais e a questão ambiental. Quimica Nova Nova, v. 33, n. 2, p. 421-430, 2010.

PAZ, A. et al. Biological treatment of model dyes and textile wastewaters. Chemosphere, v. 181, p. 168-177, 2017.

PEREIRA, W. S.; FREIRE, R. S. Ferro zero: Uma nova abordagem para o tratamento de águas contaminadas com compostos orgânicos poluentes. Quimica Nova, v. 28, n. 1, p. 130-136, 2005.

QUINA, F. H. Nanotecnologia e o meio ambiente: perspectivas e riscos. Química Nova, v. 27, n. 6, p. 1028-1029, 2004.

SHARMA, G. et al. Novel development of nanoparticles to bimetallic nanoparticles and their composites: A review. Journal of King Saud University - Science, 2017.

SHIH, Y. H.; HSU, C. Y.; SU, Y. F. Reduction of hexachlorobenzene by nanoscale zero-valent iron: Kinetics, pH effect, and degradation mechanism. Separation and Purification Technology, v. 76, n. 3, p. 268-274, 2011.

SHU, H.-Y. et al. Using resin supported nano zero-valent iron particles for decoloration of Acid Blue 113 azo dye solution. Journal of Hazardous Materials, v. 184, n. 1-3, p. 499-505, dez. 2010.

WANG, W. et al. Iron nanoparticles decoration onto threedimensional graphene for rapid and efficient degradation of azo dye. Journal of Hazardous Materials, v. 299, p. 50-58, 2015.

WEI-XIAN ZHANG. Nanoscale iron particles for environmental remediation- An overview.pdf. Journal of Nanoparticle Research, v. 5, p. 323-332, 2003.

WENG, X. et al. Enhancement of catalytic degradation of amoxicillin in aqueous solution using clay supported bimetallic Fe/Ni nanoparticles. Chemosphere, v. 103, p. 80-85, maio 2014.

ZHAI, L. et al. Fabrication of chitosan microspheres for efficient adsorption of methyl orange. Chinese Journal of Chemical Engineering, v. 26, n. 3, p. 657-666, mar. 2018.

ZHAO, D. et al. Catalytic dechlorination of 2,4-dichlorophenol by $\mathrm{Ni} / \mathrm{Fe}$ nanoparticles prepared in the presence of ultrasonic irradiation. Ultrasonics Sonochemistry, v. 21, n. 5, p. 1714-1721, 2014. 


\section{Supplementary Material}

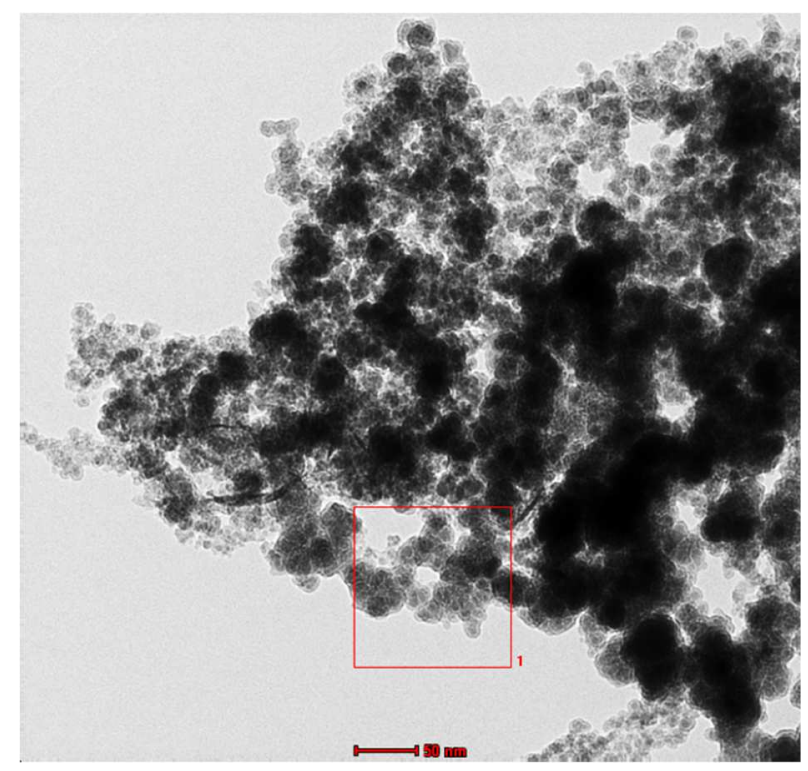

Figure 1S. Micrograph of nZVI by Transmission Electron Microscopy.

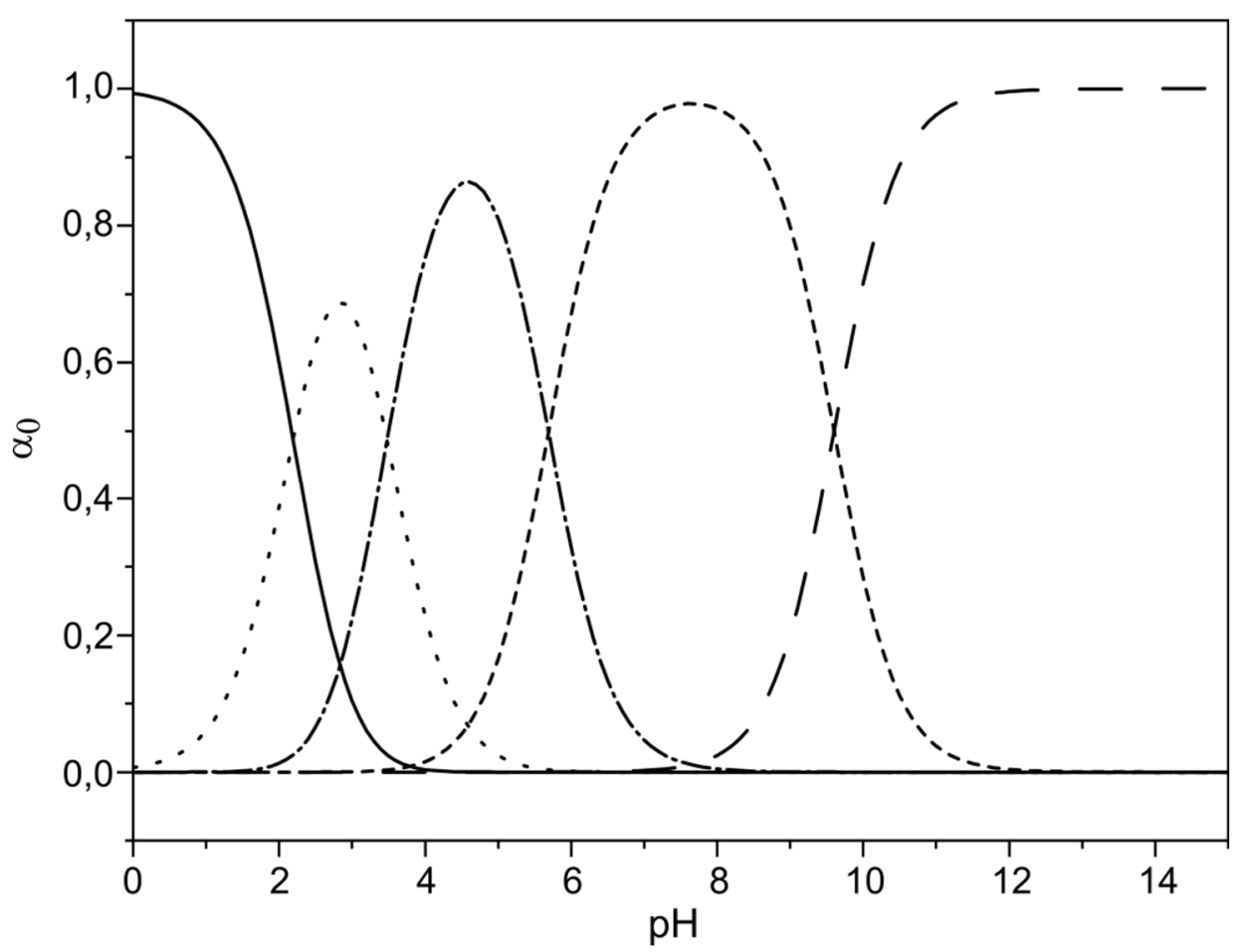

Figure 2S. Distribution of species of iron III complexes as a function of $\mathrm{pH}$. Graph generated with the TitGer spreadsheet, where " represent the specie $\mathrm{Fe}^{3+}$, “ . . . . " the ion $\mathrm{FeOH}^{2+}$, " "the ion $\mathrm{Fe}(\mathrm{OH})_{2}{ }^{+}$, “ " the ion $\mathrm{Fe}(\mathrm{OH})_{4}{ }^{-}$and " $-~-~-"$ the ion $\mathrm{Fe}(\mathrm{OH})_{3}$. 

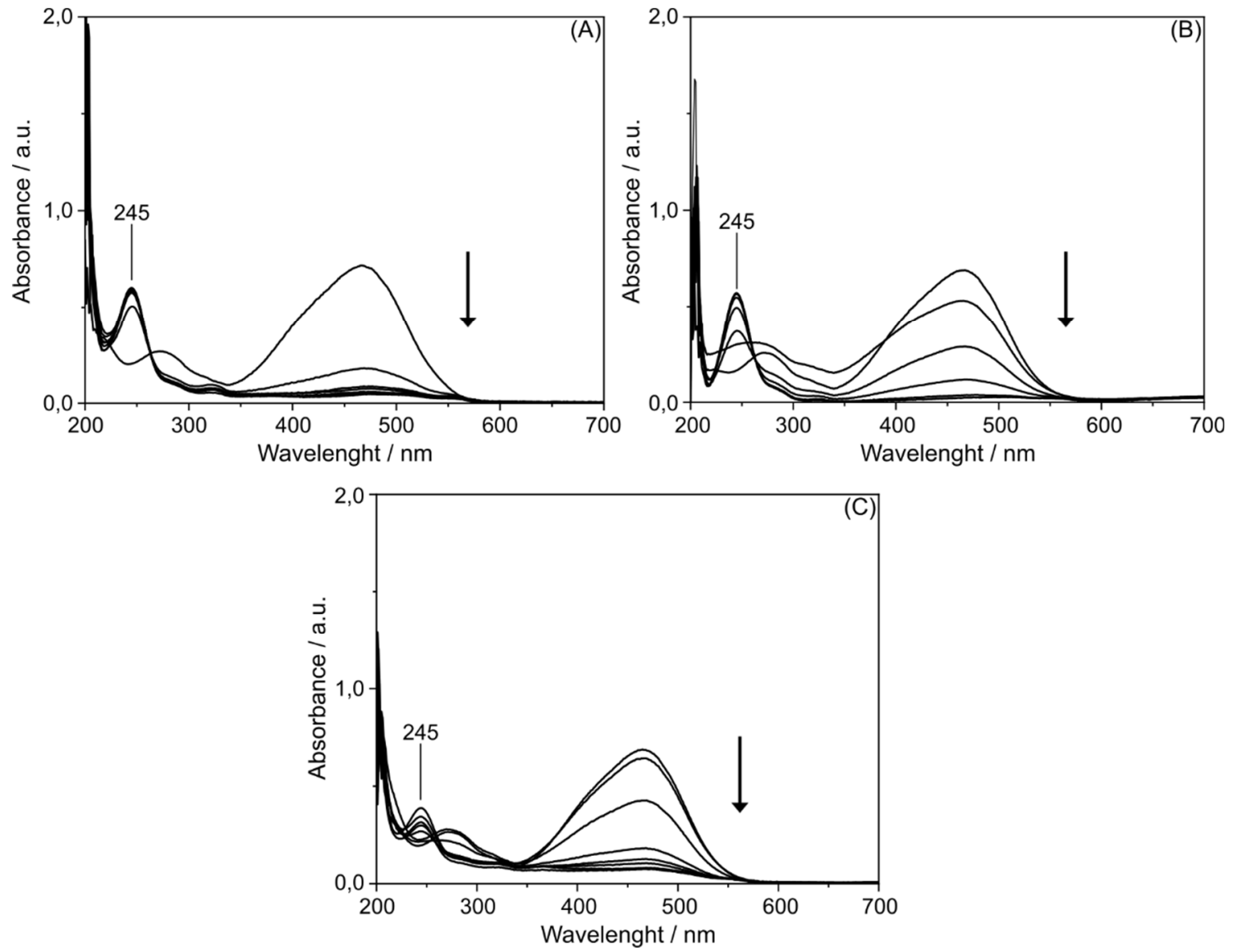

Figure 3S. UV / Vis Molecular Absorption Spectra of MO degradation as a function of time at (a) $\mathrm{pH} 2$, variation between 0 and 3,5 minutes, (b) $\mathrm{pH}$ 4, variation between 0 and 16 minutes and (c) free $\mathrm{pH}$, variation between 0 and 6 minutes.
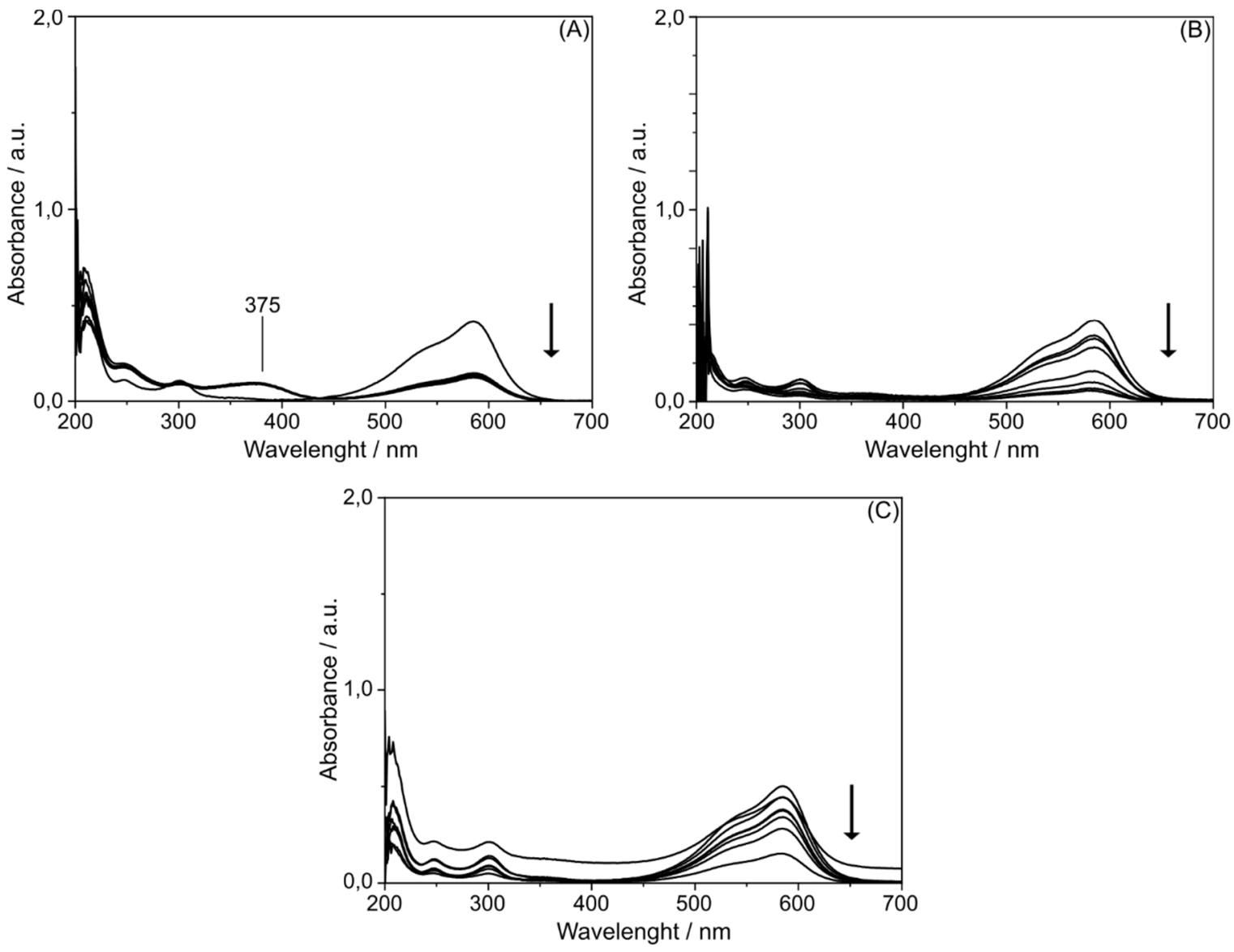
Figure 4S. UV / Vis Molecular Absorption Spectra of the MV as a function of time at (a) $\mathrm{pH}$ 2, variation between 0 and 7 minutes, (b) $\mathrm{pH} 4$, variation between 0 and 16 minutes and (c) free $\mathrm{pH}$, variation between 0 and 7 minutes.

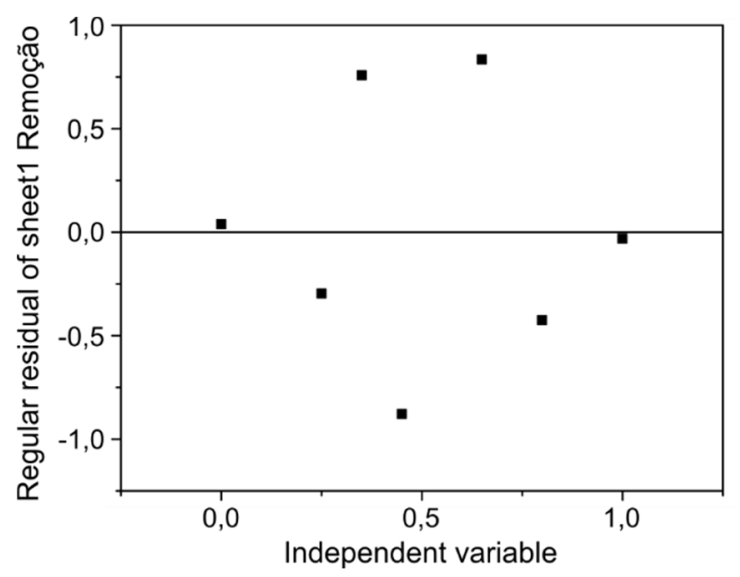

Figure 5S. Residual graph of Boltzmann Sigmoidal non-linear regression adjustment of the Standard Lot.
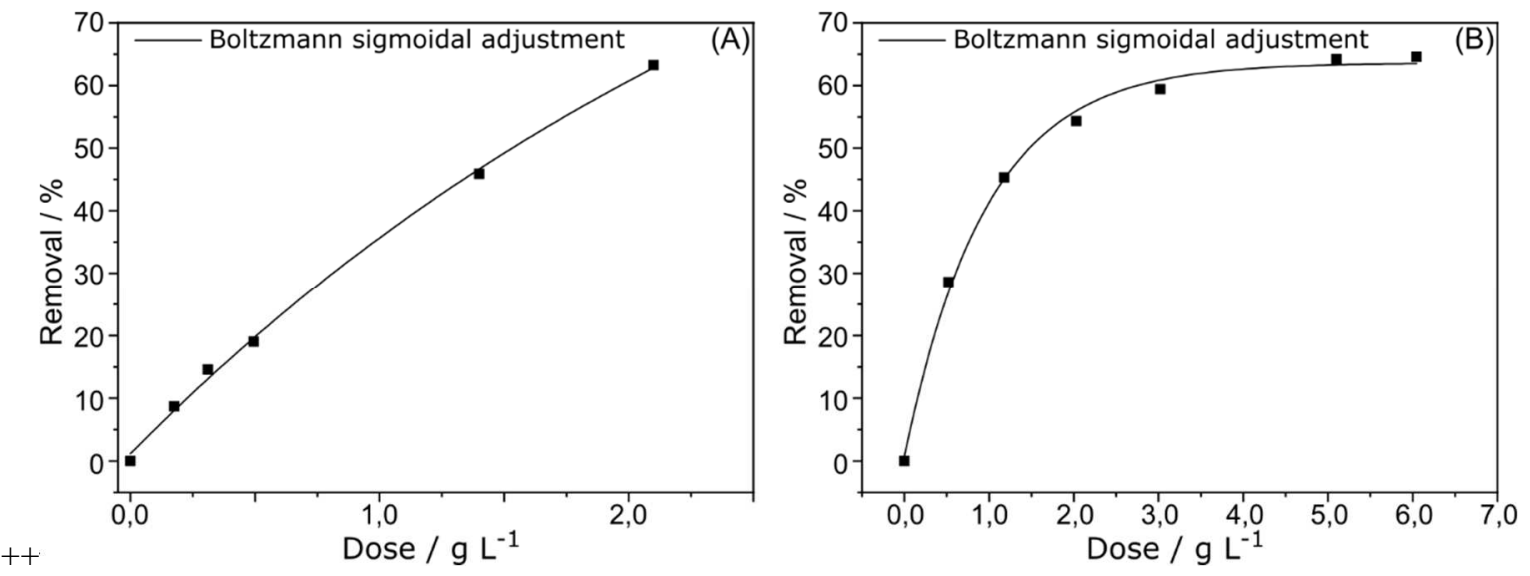

Figure 6S. Degradation of MO by nZVI of (a) Lot 01 and (b) Lot 02. Experimental conditions: $\mathrm{C}_{0}(\mathrm{MO}): 6$ $\times 10-5 \mathrm{~mol} \mathrm{~L}^{-1}$; Volume of the solution $=50 \mathrm{~mL}$ and room temperature.

$$
\begin{aligned}
& \% R=124.7185+\frac{-3225.7034-124.7185}{1+e^{\frac{D_{N P}+9.6483}{2.9572}}} \\
& \% R=63.6182+\frac{-103466.8510-63.6182}{1+e^{\frac{D_{N P}+7.1365}{0.9637}}}
\end{aligned}
$$
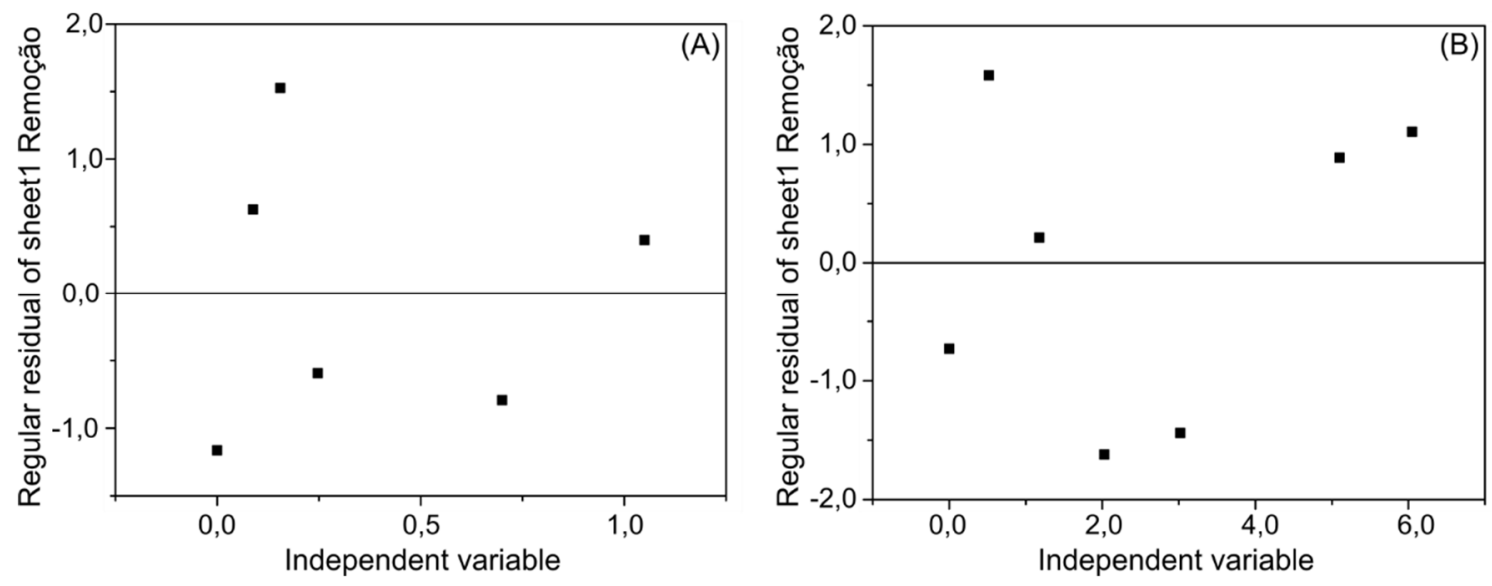
Figure 7S. Boltzmann's Sigmoidal non-linear regression residuals plot for (a) Lot 1 and (b) Lot 2.

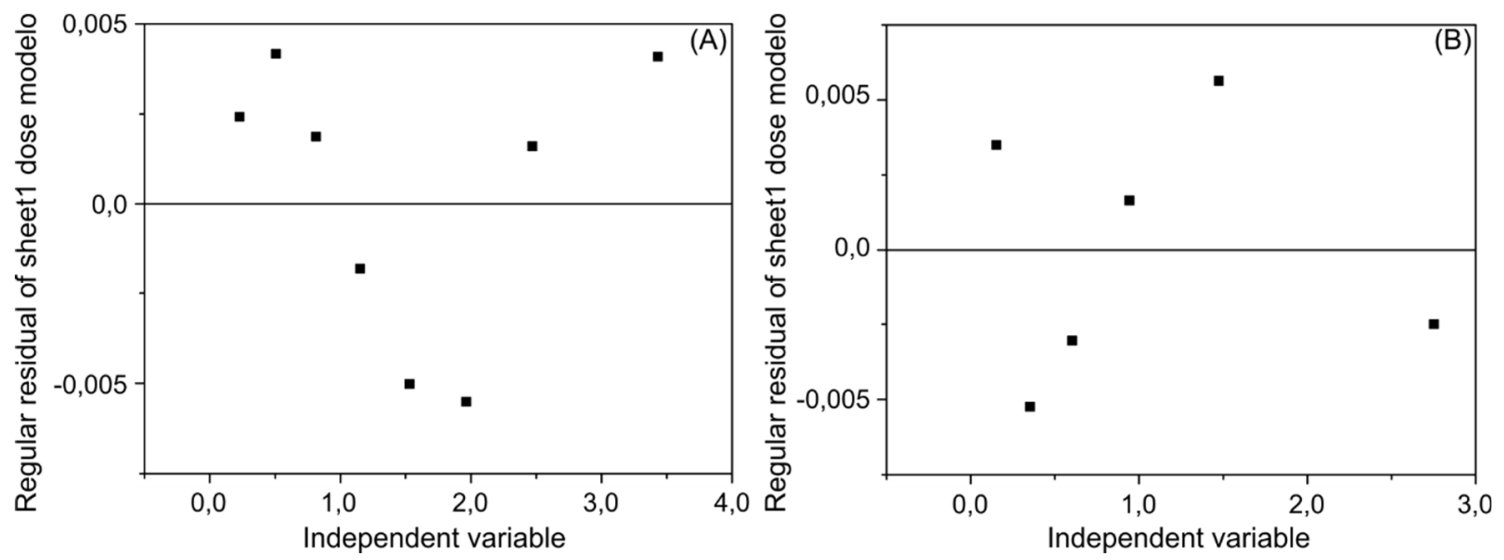

Figure 8S. Graph of residuals of the mathematical relationship between the doses of the Standard Lot with those of Lot 1 and (b) Lot 2. 